一人暮らしと夫婦暮らしの高齢女性の

生活習慣に関する研究

一 LPC 式生活習慣検査を用いた分析一

鎹吉* 大橋 綾子** 西川 浩昭***

\title{
Life Habits of the Female Elderly Who Live Alone and \\ Live with Spouse - Using the Questionnaire of "Life Planing Center Life Habits Inventory"-
}

\section{Yoshi KASUGAI*, Ayako OHASHI** and Hiroaki NISHIKAWA***}

Nowadays the proportion of the elderly living in our country rises steadily, and the changes of their socioeconomic environment and/or life-style have been largely caused by whether they live alone or live with a spouse. The quality of life is most important for these people, but previous reports concerning their health or life habits were not enough to meet social needs for this problem.

Therefore, we examiend differences in life habits and health status between the female elderly who live alone and those who live with a spouse, using the questionnaire of "Life Planning Center Life Habits Inventory". The subjects numbered 66, 35 for the former group and 31 for the latter group, who live in Kumamoto city and participated in a five-hour course for health promotion.

The results obtained were as follows;

1) Some differences in life habits were observed between the elderly living alone and those living with a spouse, and effects of living with a spouse was made clear by discriminant analysis.

2) Four factors were chosen by factor analysis, i.e., positiveness in daily behavior, psychosomatic condition, steadiness of daily living, and diretary pattern. These factors of the elderly's life habits are consistent with those which were reported for young or middle aged females, and thus are considered to be common among females in our country, regardless of age.

$*$ 尚絅短期大学家政科

** 尚絧大学文学部

*** 東邦大学医学部公衆衛生学教室

* Department of Food and Nutrition, Shokei Junior College

** Faculty of Literature, Shokei College

*** Department of Public Health, Toho University School of Medicine 
Key words : life habits, female elderly, living alone, living with spouse, life planning center life habits inventory 生活習慣，高歯女性，一人暮らし，夫婦暮らし，LPC 式生活習慣検査

\section{I 緒 言}

現在，我が国は人口の高歯化に直面している. 厚生省人口問題研究所の推計によると 2020 年には 4 人に 1 人が 65 歳以上の高齢者という超高齢社会 をむかえる（厚生省1992）とともに，1990年から 2010年までに高齢者世帯の $70 \%$ 近くが夫婦のみの 世帯（約 530 万）と一人暮らしの世帯（約 460 万） になるとしている（厚生省1995）。

一方，高齢者をとりまく生活環境や社会全体の ライフスタイルの変化等から多くの「一人暮らし」 や「夫婦のみ」の高齢者が急增してきており, 熊 本県も例外ではない.これらの高齢者にとっては, 日常生活のあり方は最も重要な問題となってい る. 特に高柃者の一人暮らしの場合は, 他からの 介助や助言が少なくなるなど, 生活形態としては 不利であると考えられる。

この様な状況下において, 地域保健活動に求め られているものとして, 高齢者の生きがいと健康 づくりがあげられる．にも拘らず，これらに関す る研究は必ずしも十分であるとはいい難い.また, 高齢者の健康の維持増進のためには，高齢者自身 の啓蒙が急務であり，そのためには自分自身で各 自の生活習慣を把握する必要があると考えられ る.こうした啓蒙活動の一環として, 我々は高齡 者の生き甲斐や健康生活に資する目的で，地域在 住の高齢者を対象とした公開講座「すこやかシル バーカレッジ」を熊本市福祉公社ヒューマンライ フとの提携で実施した。講座の内容は, 講演と料 理教室および留親会を兼ねた試食会からなり，要 した時間は全体で 4 〜 時間であったが，高齢者 の健康増進に対する意欲を促進するものとして有 効な手段であると考えられる，さらに，その内容 の一環として LPC 式生活習慣調査票を用いて高 齢者の生活習慣についての調查を実施した。

本論文は，この講座に出席した熊本市に在住す
る高齢女性を対象として実施した生活習慣につい ての調査結果の報告であり，さらにその実態や背 景となっている要因を「一人暮らし」の高噛女性 と「夫婦暮らし」の高齢女性について比較検討し たものである.

\section{II 対象および方法}

\section{1. 対象}

本研究の対象者は平成 5 年度に著者の所属する 大学 (学長 三村悟郎) と熊本市福祉公社ヒュー マンライフとの共同主催の「高龄者のための公開 講座」に参加した，65歳以上の特に重篤な疾患を 有しない熊本市在住の一人暮らし高齢女性 35 名, 夫婦暮らし高齢女性31名，計66名である．以下一 人暮らし高齢女性を「一人暮らし」，夫婦暮らし高 齢女性を「夫婦暮らし」と略称する，対象者の抽 出は, 熊本市中心部の本学を中心とした 5 小学校 学区に在住している65歳以上の高榆女性 $(3,864$ 人）に対して，市政だより等の広報に応募したも のである。なお, 本研究の対象者 66 名は, 対象地 区に居住する高龄女性の $1.7 \%$ に相当するが，「一 人暮らし」，「夫婦暮らし」人口のそれぞれ $6.8 \%$ ， $9.0 \%$ に相当する.対象者が参加した公開講座は平 日の午前中に実施され，高齢者の生きがいについ ての講演を 2 題と，高齢者にふさわしい料理の調 理講習会と試食会からなっており，重篤な疾患を 有するものでなければ，誰でも容易に参加できる ものである，こうした点を考虑すると，本研究で 用いた対象は, 参加できる程度に ADL を備え, 積 極性がある人たちであると考えられるが，それ以 外の地区, 学歷, 職歷, 経済的背景などには偏り がない.

\section{2. 調査方法}

調查は自記式留置法により実施した。具体的に は, 講座終了時に, 記入方法を説明した後に調査 票を手渡し，一旦持ち帰らせて，各自記入させた。 
数日後に調査員が対象者宅を訪問し面接して，必 要があれば記入の援助をし，丁寧に補完して回収 した。調査員は栄養士 8 名, 管理栄養士 1 名, ヒューマンライフ公社職員 2 名からなり, 調査に は30人日を要した。

\section{3. 調査内容}

本調査は, LPC 式生活習慣検査システム「生活 習慣ドック調査票」を用いて実施した。この質問 票は, 学歷, 職業, 年齢, 居住地など個人属性, 生活習慣，および血圧，身長，体重等の身体状況 に関する質問により構成されており，生活習慣に 関する質問は食習慣, 余暇の使い方, 人間関係と 生活態度，心身の健康状態，既往症の有無などに より構成されており,質問項目数は全部で148問で ある。なお，被調查者の生活習慣については，個々 の質問の回答で判断するのではなく，ある項目に 属するいくつかの質問の回答結果を集約した，尺 度得点（19尺度）を分析の変数として用いた（付 表).

ここで用いた尺度得点は LPC 式生活習慣調査 票の版権をもつ日本医療情報システム株式会社に より報告された尺度得点であり，各尺度について 100 点満点に変換された值である.なお，19尺度の うち,「肉・油脂」,「塩分」,「糖分」,「病気がち」, 「多愁訴」については，質問の回答を反転し，いず れも回答が低い方が高得点になるよう, 具体的に は「肉・油脂」，「塩分」，「糖分」の 3 尺度につい ては摂取量が少ない場合，「病気がち」，「多愁訴」 の 2 尺度については訴えが少ない場合が，高得点 となるように変換されていた。

分析方法は個人の属性に関する質問や生活習慣 尺度得点についての単純集計，また各回答状況に ついて検討するために項目ごとに一人暮らし，夫 婦暮らし別に年齢とのクロス集計を試み，さらに 生活形態に影響を与えている尺度を明らかにする 目的で，「一人暮らし」，「夫婦暮らし」という生活 形態を外的基準として判別分析を行い，得られた 判別関数の係数から外的基準である生活形態の分 類に影響する尺度を明らかにすることを試みた （高木1995）。また，対象者の生活習慣尺度につい
て因子分析を用いて，変数の要約（次元圧縮）を 試みた。なお，生活習慣については，年齢による 影響が大きいと考えられ，年齢との関連について も検討を試みた。

分析には，パソコン版統計パッケージ HALBAU-4（高木1994），および東京大学大型計 算機センターHITAC M880/310システムの SAS およびSPSSX（三宅ら1991）を用いた。

\section{III 成 績}

1. 対象者の属性

本調査で用いた対象の基本属性を表 1 に示し た。年齢については一人暮らし，夫婦暮らしとも に70歳代にピークを有し，特に一人暮らしでは 75〜79歳（48.6\%）が，夫婦暮らしでは70〜 74歳 $(45.2 \%)$ が多かった。平均年齢は一人暮らし 76.4 歳, 夫婦暮らし 70.0 歳と有意差が見られた。職業 については, 一人暮らし, 夫婦暮らしとも無職(主 婦)が最も多く，両群の間に差は見られなかった。 対象者本人が，健康であると回答した者は，一人 暮らし $51.4 \%$ ，夫婦暮らし $67.8 \%$ であり，夫婦暮 らしが一人暮らしを上回ったが有意差は見られな かった。既往歴については循環器系の疾患が多く, 両群の間に差は見られなかった．現在の「血圧」 について，一人暮らしでは，「正常」57.1\%，「境 界域」42.9\%であり，「高血圧」と判定された者は いなかった。他方，夫婦暮らしでは「正常」が $67.7 \%$ ，「境界域」25.8\%であり，「高血圧」は $6.5 \%$ と少なかった。体格指数 BMI については，記入さ れた身長・体重值から計算したが，一人暮らし， 夫婦暮らし両群間に統計的な差は認められなかっ た，住民健診等の受診状況については，夫婦暮ら しでは全員が何等かの健診を受診していたが，一 人暮らしでは 6 名（17.0\%）が受診していなかっ た。学歴については夫婦暮らしの方が高かった。

2. 生活習慣の内容一生活形態間の相違一

1）平均值の比較

一人暮らし, 夫婦暮らし両群について, 100 点満 点に変換した生活習慣の各尺度の尺度得点の平均 值を表 2 に示した。 
両群間で統計的に有意差がある尺度は,「料理の 関心と工夫」 $(\mathrm{p}<0.01)$ ，「娛楽」 $(\mathrm{p}<0.01)$ であ り, 両尺度とも夫婦暮らしが一人暮らしを上回っ ていた(図 1)。また統計的には有意ではなかった が，夫婦暮らしが一人暮らしを上回る尺度として は, 「食事の規則性」,「社会奉仕」,「義理人情」, 「節約」, 「清潔」, 「運動」, 「多愁訴」,「外向性・自
発性」,「病気がち」であり, 逆に一人暮らしが夫 婦暮らしを上回る尺度としては「肉・油脂」,「塩 分」,「糖分」,「情緒安定」であった。

2）判別分析による検討

一人暮らし, 夫婦暮らしの別を外的基準とし, 生活習慣の各尺度得点を独立変数として判別分析 を行い，その結果である標準化判別係数を表 3 に

付表 LPC 式生活習慣ドックの尺度内容

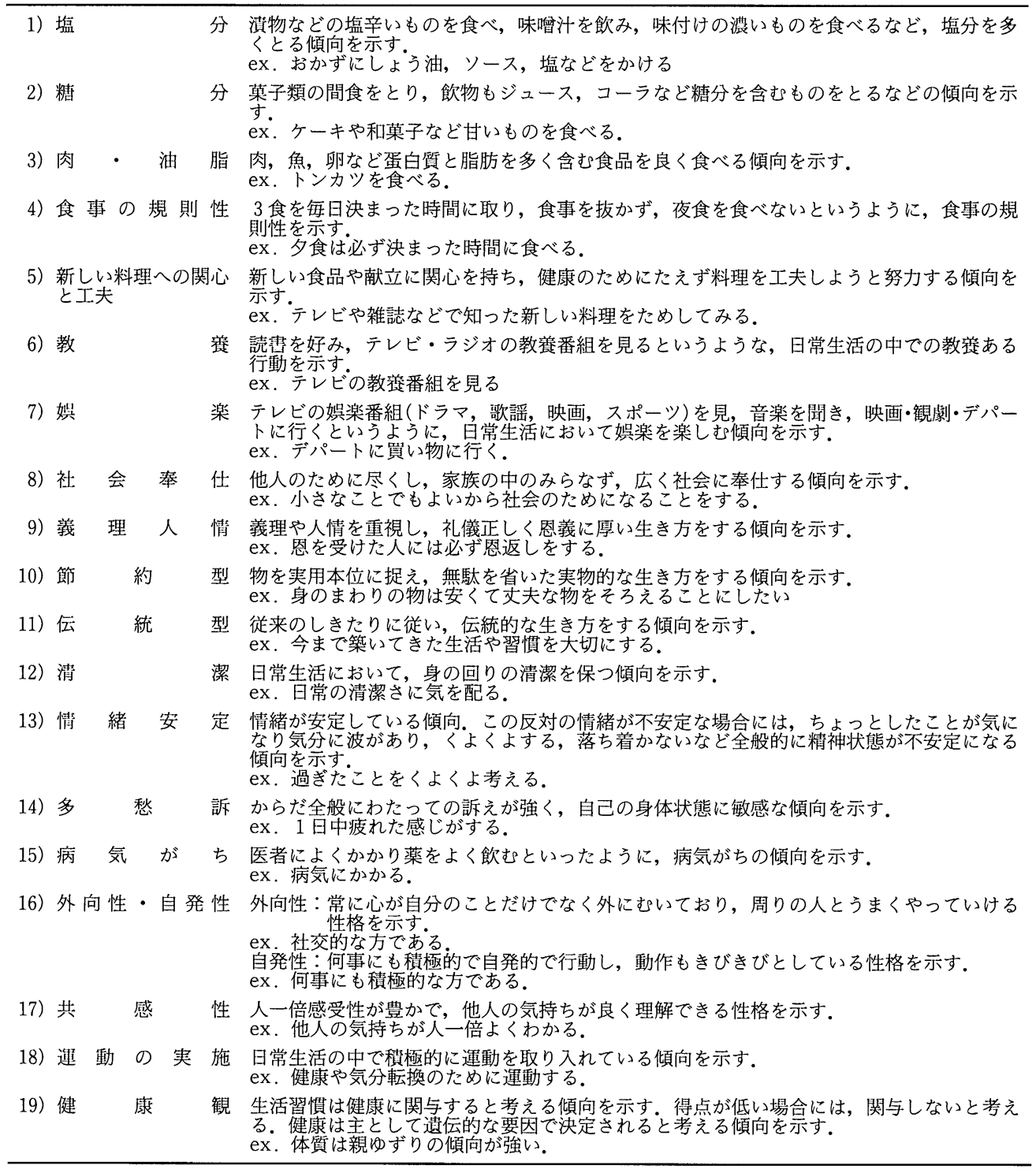


表 1 調査対照の構成

\begin{tabular}{lrrrrr} 
(a) 年 齢 & & & & & 人 $(\%)$ \\
\hline & 65未満 & $65 \sim 69$ & $70 \sim 74$ & $75 \sim 79$ & 80 以上 \\
\hline 一人暮らし $(\mathrm{n}=35)$ & $0(0.0)$ & $2(5.6)$ & $8(22.9)$ & $17(48.6)$ & $8(22.9)$ \\
夫婦暮らし $(\mathrm{n}=31)$ & $5(16.1)$ & $6(19.4)$ & $14(45.2)$ & $5(16.1)$ & $1(3.2)$
\end{tabular}

\begin{tabular}{ccc}
\hline (b) 職 業 & & \\
\hline & あり & 無 \\
\hline 一人暮らし $(n=35)$ & $3(8.6)$ & $32(91.4)$ \\
夫婦暮らし $(n=31)$ & $4(12.9)$ & $27(87.1)$ \\
\hline
\end{tabular}

(c) 健 康 観

\begin{tabular}{lrrrr}
\hline & 健 康 & $\begin{array}{c}\text { どちらとも } \\
\text { いえない }\end{array}$ & 不健康 & 無回答 \\
\hline 一人暮らし $(\mathrm{n}=35)$ & $18(51.4)$ & $12(34.3)$ & $3(8.6)$ & $2(5.7)$ \\
夫婦暮らし $(\mathrm{n}=31)$ & $21(67.8)$ & $9(29.0)$ & $1(3.2)$ & $0(0.0)$ \\
\hline
\end{tabular}

(d) 病 歴

\begin{tabular}{|c|c|c|c|c|c|c|}
\hline & 高血圧 & $\begin{array}{c}\text { 高コレステロール } \\
\text { 血 }\end{array}$ & 糖尿病 & 狭心症 & 心筋梗塞 & その他 \\
\hline 一人暮らし $(n=35)$ & $12(52.5)$ & $4(17.4)$ & $3(13.1)$ & $1(4.3)$ & $2(8.7)$ & $1(4.3)$ \\
\hline 夫婦暮らし $(n=31)$ & $16(64.0)$ & $5(20.0)$ & $1(4.0)$ & $0(0.0)$ & $0(0.0)$ & $3(12.0)$ \\
\hline
\end{tabular}

(e) 血 圧

\begin{tabular}{lcc}
\hline & 一人暮らし $(\mathrm{n}=35)$ & 夫婦暮らし $(\mathrm{n}=31)$ \\
\hline 正 常 & $20(57.1)$ & $21(67.7)$ \\
境 界 域 & $15(42.9)$ & $8(25.8)$ \\
高血圧 & $0(0.0)$ & $2(6.5)$ \\
\hline
\end{tabular}

( f ) Body Mass Index

\begin{tabular}{lcc}
\hline & 一人暮らし $(\mathrm{n}=35)$ & 夫婦暮らし $(\mathrm{n}=31)$ \\
\hline 平 均 值 & 21.7 & 22.6 \\
標 準 偏 差 & 3.0 & 3.1 \\
変動係数 $(\%)$ & 13.9 & 14.2 \\
\hline
\end{tabular}

(g) 検診の受診状況

\begin{tabular}{lccccc}
\hline & 住民検診 & 胃ガン検診 & 会社での検診 & 循環器検診 & 受けていない \\
\hline 一人暮らし $(\mathrm{n}=35)$ & $19(54.3)$ & $8(22.9)$ & $1(2.9)$ & $1(2.9)$ & $6(17.0)$ \\
夫婦暮らし $(\mathrm{n}=31)$ & $27(87.1)$ & $4(12.9)$ & $0(0.0)$ & $0(0.0)$ & $0(0.0)$ \\
\hline
\end{tabular}

(h) 学 歴

\begin{tabular}{lrrrr}
\hline & 小学校 & 高等小学校 & 旧中・旧女 & 旧高・専 \\
\hline 一人暮らし $(\mathrm{n}=35)$ & $2(5.7)$ & $17(48.5)$ & $16(45.8)$ & $0(0.0)$ \\
夫婦暮らし $(\mathrm{n}=31)$ & $1(3.2)$ & $5(16.1)$ & $23(74.2)$ & $2(6.5)$ \\
\hline
\end{tabular}

示した. 判別関数による判別的中率は $84.9 \%$ と高 く, 分析結果として良好である. 一人暮らし, 夫 婦暮らし両群の判別得点の重心は, それぞれ
-0.786および0.887であるので, 判別係数が負の 尺度の得点が大きければ一人暮らしに，小さけれ ば夫婦暮らしに判別される可能性が高くなり, 逆 
表 2 生活形態別の生活習慣等の状況

\begin{tabular}{|c|c|c|c|c|c|c|c|c|c|}
\hline \multirow{2}{*}{\multicolumn{3}{|c|}{ 変 数 名 }} & \multicolumn{3}{|c|}{ 一人慕らし $(\mathrm{n}=35)$} & \multicolumn{3}{|c|}{ 夫婦裮らし $(n=31)$} & \multirow{2}{*}{ 有意差 } \\
\hline & & & 平均値 & 標準偏差 & 変動係数 & 平均値 & 標準偏差 & 変動係数 & \\
\hline 年 & & 歯 & 76.4 & 4.0 & 5.3 & 70.0 & 5.3 & 7.7 & $* * *$ \\
\hline 肉 & $\cdot$ & 油 & 76.0 & 17.8 & 23.4 & 72.6 & 14.8 & 20.3 & \\
\hline 塩 & & 分 & 65.4 & 22.4 & 34.3 & 59.6 & 22.2 & 37.2 & \\
\hline 糖 & & 分 & 70.1 & 22.0 & 31.4 & 64.8 & 24.0 & 37.0 & \\
\hline 食身 & 事の & 規 則 性 & 70.0 & 33.8 & 48.3 & 78.3 & 25.4 & 32.5 & \\
\hline 料理 & の関， & 心とて夫 & 55.7 & 21.4 & 38.4 & 71.6 & 21.0 & 29.3 & $* *$ \\
\hline 娱 & & 楽 & 45.8 & 22.9 & 50.0 & 60.6 & 21.4 & 35.3 & $* *$ \\
\hline 教 & & 等 & 59.3 & 24.6 & 41.5 & 59.8 & 22.2 & 37.0 & \\
\hline 社 & 会 & 奉 & 52.8 & 25.8 & 48.9 & 57.2 & 25.1 & 43.9 & \\
\hline 義 & 理 & 人 & 65.0 & 27.0 & 41.5 & 74.1 & 20.9 & 28.1 & \\
\hline 節 & & 約 & 47.0 & 19.5 & 41.6 & 56.4 & 20.9 & 37.2 & \\
\hline 伝 & & 統 & 73.4 & 22.7 & 30.9 & 79.9 & 22.3 & 27.9 & \\
\hline 清 & & 潔 & 64.8 & 26.6 & 41.0 & 72.1 & 21.4 & 29.7 & \\
\hline 運 & & 動 & 57.8 & 21.5 & 37.2 & 63.9 & 15.7 & 24.6 & \\
\hline 病 & 文 & が & 44.7 & 19.6 & 43.9 & 55.1 & 22.4 & 40.6 & \\
\hline 多 & 愁 & 訴 & 61.4 & 32.0 & 52.2 & 67.3 & 26.4 & 39.2 & \\
\hline 情 & 緒 & 安 定 & 66.7 & 26.4 & 39.6 & 63.2 & 27.5 & 43.5 & \\
\hline 外向 & 问性 . & 自発性 & 64.6 & 21.8 & 33.8 & 68.4 & 22.7 & 33.1 & \\
\hline 共 & 感 & 性 & 62.4 & 25.2 & 40.4 & 60.2 & 25.5 & 42.3 & \\
\hline 健 & 康 & 観 & 52.3 & 22.7 & 43.4 & 53.2 & 24.0 & 45.2 & \\
\hline
\end{tabular}

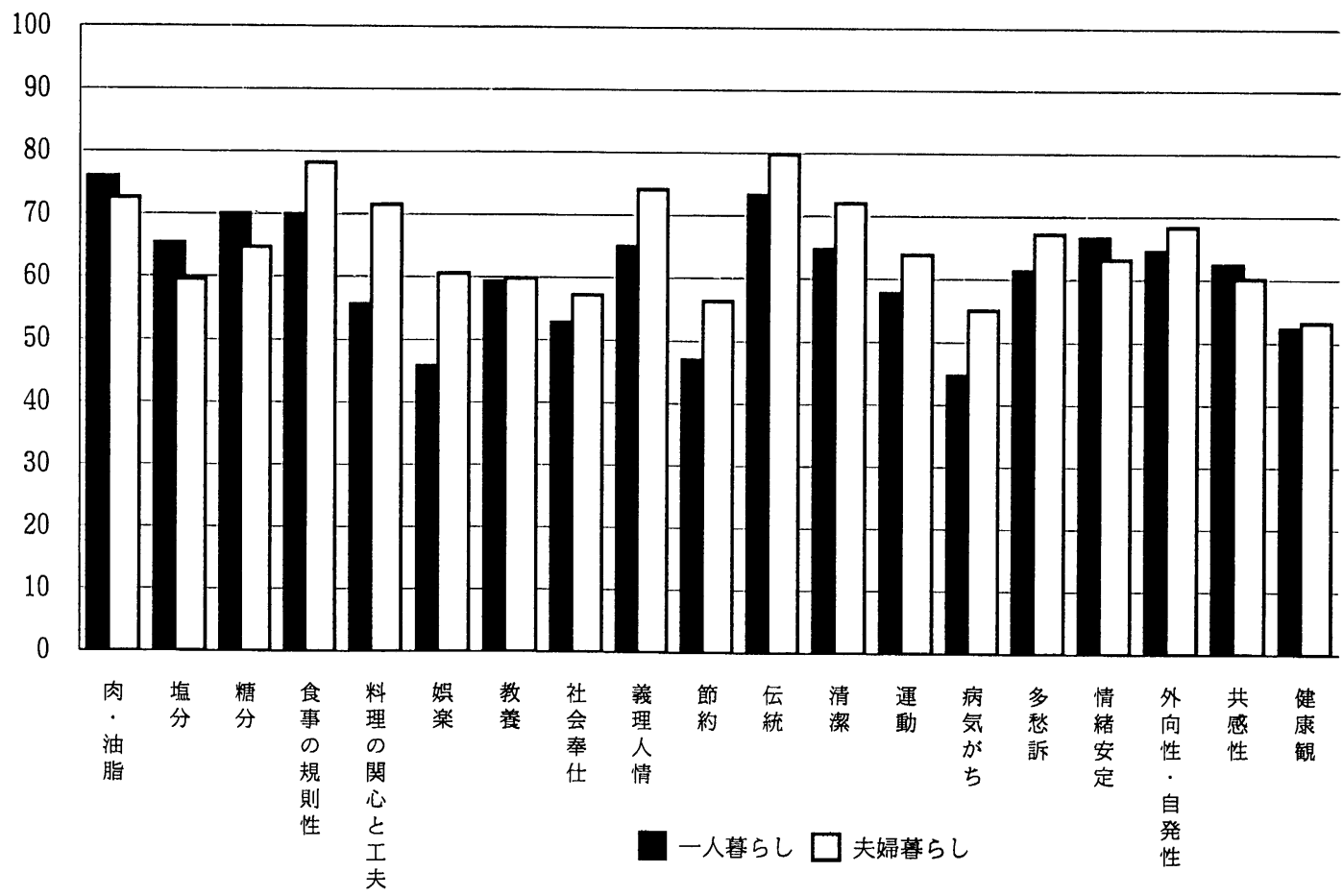

図 1 生活習慣等の状況（女性高粭者）

一人暮らし・夫婦暮らしの平均値 
表 3 標準化判別係数

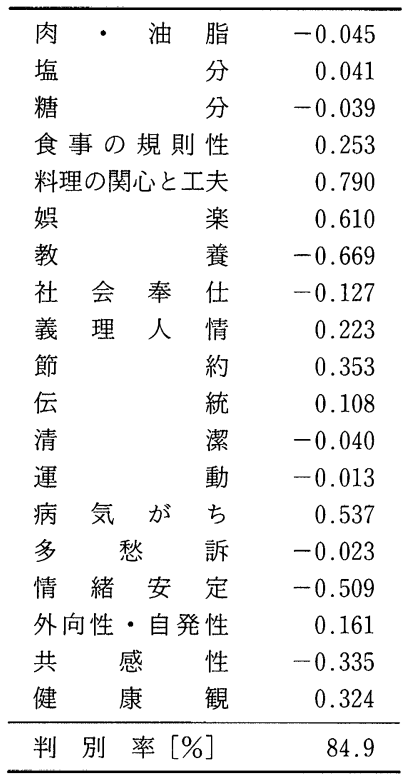

に判別係数が正の尺度が大きければ夫婦暮らし に, 小さければ一人暮らしに判別される可能性が 高くなることになる. 具体的には, 判別係数が負 で絶対值が大きい「教養」( -0.669$)$,「情緒安定」 $(-0.509)$, 「共感性」(-0.335) の尺度得点が大 きければ一人暮らしに, 小さければ夫婦暮らしに 判別されることになる. 他方, 判別係数が正で絶 対値が大きい「食事の規則性」(0.253),「料理の 関心と工夫」(0.790), 「娛楽」(0.610), 「節約」 (0.353), 「病気がち」(0.537), 「健康感」(0.324) の尺度得点が大きければ夫婦暮らしに，小さけれ ば一人暮らしに判別されることになる。

3. 生活習慣尺度間の相関係数

一人暮らしと夫婦暮らし別に生活習慣の尺度 （19尺度）間の相関係数を表 4 に示した.

1）一人暮らし群

統計的に有意な相関係数が得られた尺度の組み 合せは，正相関のものでは「共感性」一「義理人情」 $(\mathrm{r}=0.719)$ 等 35 組におよび, 負相関のものでは 2 組で「肉・油脂」一「節約」 $(\mathrm{r}=-0.391)$,「健康観」 一「娛楽」 $(\mathrm{r}=-0.347)$ であった。これは, 肉や油 脂の摂取が少なければ，節約しているという様に

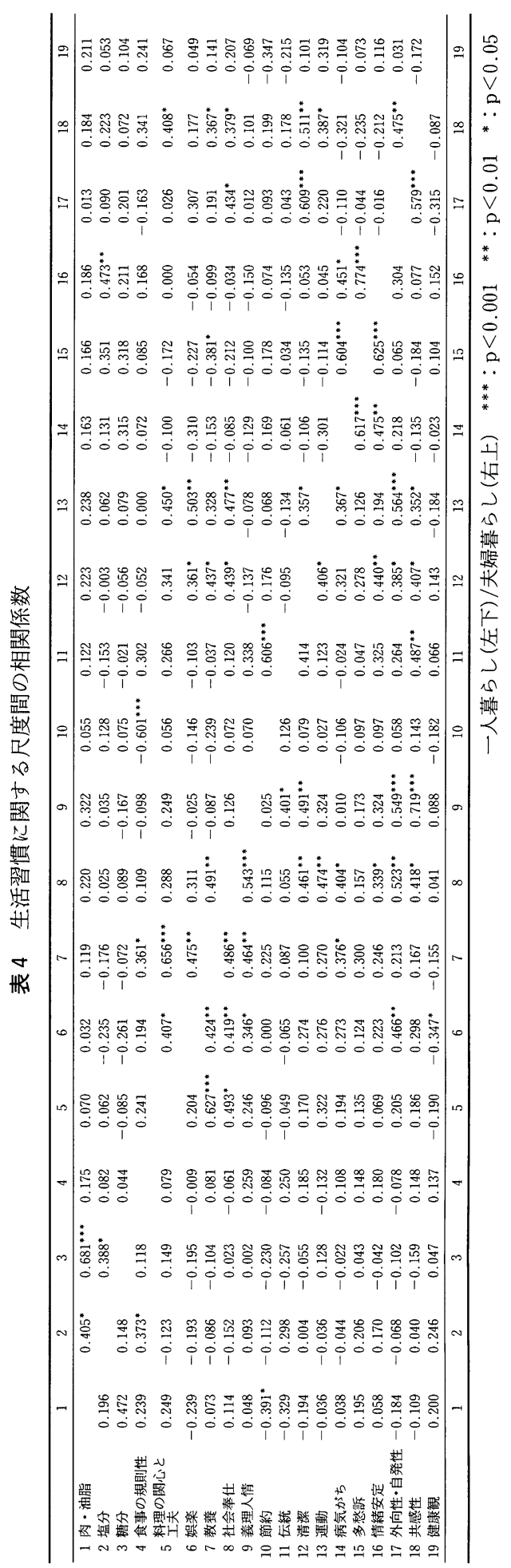


一般的なコンセンサスに合致している。

2）夫婦暮らし群

統計的に有意な相関関係が得られた尺度の組み 合せは，正相関のものでは「情緒安定」一「多愁訴」 $(\mathrm{r}=0.774)$ 等 26 組があり，一方，負相関を示すも のは 2 組であり「食事の規則性」一「節約」 $(r=-$ $0.601)$, 「教養」一「多愁訴」( $\mathrm{r}=-0.381)$ であっ た．これは，情緒が安定している場合には，愁訴 が少ない様に一般的なコンセンサスに合致してい るものがある反面，食事を規則的に攝っている者 では節約性に欠けるなど理想としてのコンセンサ スには合致しないが，より現実的な状況が現れて いた。

\section{4. 因子分析}

一人暮らし，夫婦暮らしの高齢女性の生活習慣 の背景となっている因子を探索することを目的と して因子分析（主因子法・バリマックス回転）を 行い, 抽出された因子のうち, 固有值 1 以上であっ た第 4 因子までの因子負荷量を寄与率とともに示 した.第 4 因子までの累積寄与率は $44.2 \%$ あり,
第 1 因子および第 2 因子では，全体の $27.2 \%$ が説 明された（表 5 ）。

因子分析により得られた因子空間に与える影響 の程度を判断する指標である共通性では，「多愁 訴」(0.834), 「共感性」(0.790), 「肉・油脂」(0.716) といった尺度が高く，逆に「食事の規則性」 (0.076), 「健康感」(0.091)の共通性は低功た。 これは, 愁訴, 共感性, 肉・油脂などの尺度につ いては因子空間に対する寄与が大きく, 得られた 因子で説明が可能であるが，食事の規則性や健康 感については，固有因子の影響が大きく，独自性 が高いことになる。

この様にして得られた因子のうち, 第 1 因子と 第 2 因子，および第 3 因子と第 4 因子により，そ れぞれ因子による二次元空間を作り，尺度をその 負荷量に従って空間内に付置させた（図 $2 ， 3$ ). 第 1 因子は,「社会奉仕」,「教養」,「料理の関心 と工夫」,「娛楽」,「運動」,「清潔」,「外向性・自 発性」,「共感性」などの尺度の負荷量が高く, 積 極性・活発性および行動力に起因する因子である.

表 5 19尺度の因子分析(バリマックス回転)

\begin{tabular}{|c|c|c|c|c|c|}
\hline & 因子 1 & 因子 2 & 因子 3 & 因子 4 & 共通性 \\
\hline - 油 脂 & 0.106 & 0.051 & -0.250 & 0.800 & 0.716 \\
\hline 塩 & -0.148 & 0.156 & 0.236 & 0.501 & 0.353 \\
\hline 糖分 & -0.077 & 0.062 & -0.085 & 0.585 & 0.359 \\
\hline 食 事 の 規 則 性 & 0.112 & 0.175 & -0.122 & 0.135 & 0.076 \\
\hline 料理の関心と工夫 & 0.625 & 0.052 & -0.059 & -0.017 & 0.397 \\
\hline 娛少 & 0.616 & 0.075 & -0.040 & -0.322 & 0.490 \\
\hline 教 & 0.713 & 0.064 & -0.219 & -0.024 & 0.560 \\
\hline 会 奉 & 0.727 & 0.047 & 0.126 & 0.109 & 0.559 \\
\hline 理 人 & 0.418 & 0.027 & 0.367 & -0.011 & 0.311 \\
\hline 節 & -0.085 & 0.111 & 0.465 & -0.218 & 0.283 \\
\hline 伝 & 0.091 & 0.061 & 0.548 & -0.136 & 0.331 \\
\hline 清 & 0.519 & 0.164 & 0.382 & -0.006 & 0.442 \\
\hline 運 & 0.571 & 0.056 & 0.157 & 0.031 & 0.355 \\
\hline 気 が & 0.115 & 0.663 & -0.035 & -0.001 & 0.454 \\
\hline 愁 & -0.018 & 0.890 & 0.111 & 0.171 & 0.834 \\
\hline 情 緒 安 定 & 0.096 & 0.691 & 0.189 & 0.201 & 0.563 \\
\hline 外向性 - 自発性 & 0.513 & 0.005 & 0.411 & -0.094 & 0.441 \\
\hline 共感 性 & 0.508 & -0.360 & 0.616 & 0.152 & 0.790 \\
\hline 康 & 0.009 & 0.074 & -0.108 & 0.272 & 0.091 \\
\hline 因子負荷囸の 2 乘和 & 3.188 & 1.967 & 1.640 & 1.610 & 8.406 \\
\hline 奇与率 $[\%]$ & 16.8 & 10.4 & 8.6 & 8.5 & 44.2 \\
\hline
\end{tabular}




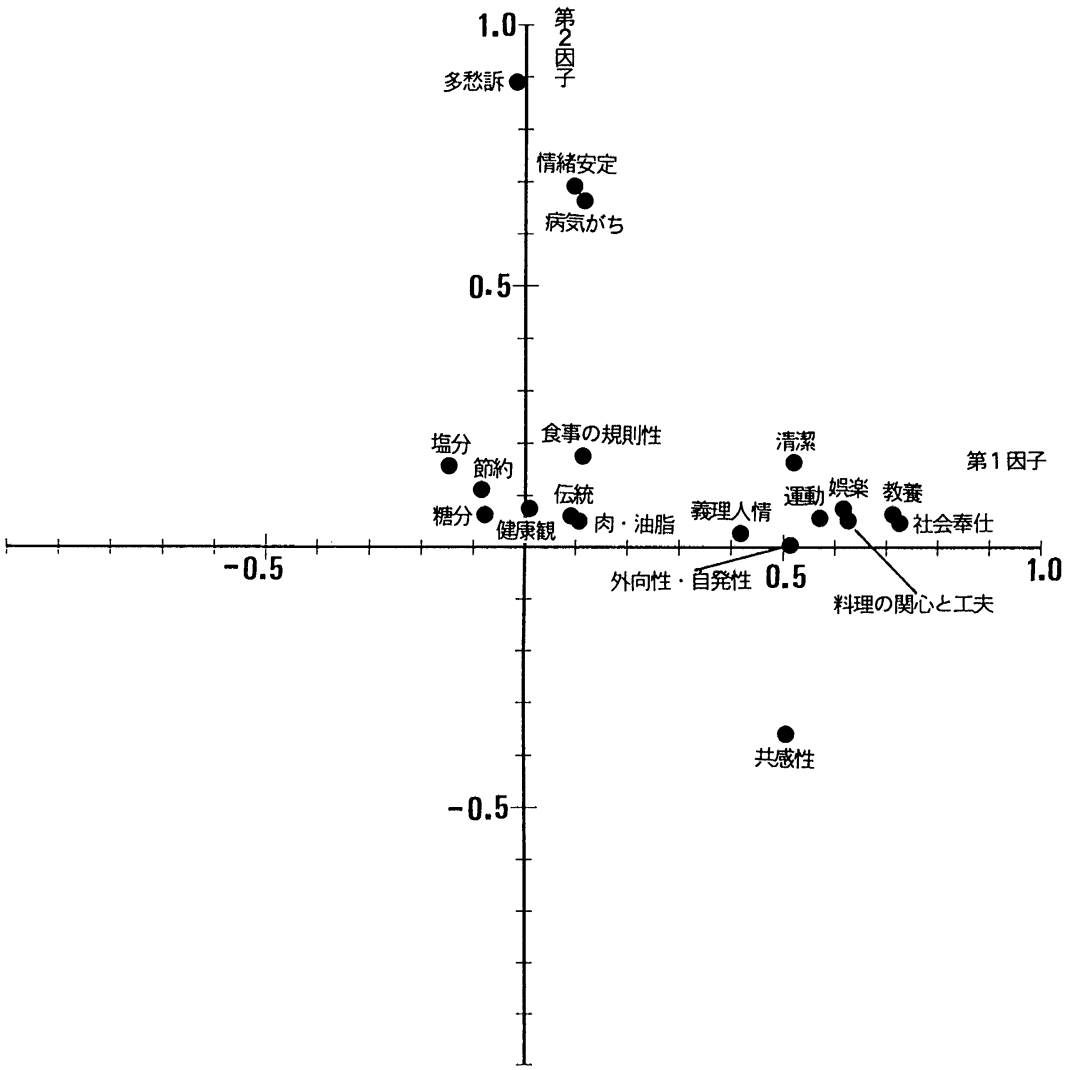

図 2 生活習慣等の状況（女性高齢者）

因子分析による空間付置（第 $1 ・ 2$ 因子）

第 2 因子は,「多愁訴」,「情緒安定」,「病気がち」 などの負荷量が高く，心身の状態に起因する因子 である。

第 3 因子は，「共感性」，「伝統」，「節約」などの 負荷量が高く，生活の堅実さに起因する因子であ る.

第 4 因子は「肉・油脂」，「糖分」，「塩分」など の負荷量が多く，食事に起因する因子である.

この結果として, 本研究で用いた高齢者の生活 習慣は, 積極性・活動性・行動力, 心身の状態, 生活の堅実さ，食事からなる 4 次元空間に投影す ることが可能であり，この 4 つの成分に要約する ことが可能となった。言い換えれば，本研究の対 象の生活習慣の要約統計量としてこの 4 成分を用 いることが可能となる。
5. 生活形態別に見た生活習慣パターン

因子分析の際に算出された各個人の因子得点を 生活形態別に平均値で示して比較した(表 6 ). 全 ての因子について生活形態による統計的な差は見 られなかったが，第 4 因子については $\mathrm{p}=0.07$ と 有意ではないが，やや大きな差が見られた。これ は，一人暮らしに比べ夫婦暮らしの方が食事に注 意を払っていないことを示している.

6. 年齢が生活習慣に及ぼす影響について

年齢と各生活習慣尺度およびそれらを要約した 因子得点（第 1 ～第 4 因子）との関係を，一人暮 らしと夫婦暮らしおよび全対象について調べるた めに，それぞれの相関係数を求め表 7 に示した. 多くの尺度で，負の相関が見られ年齢の上昇に 伴って，生活習慣の活動性が低下していることが 


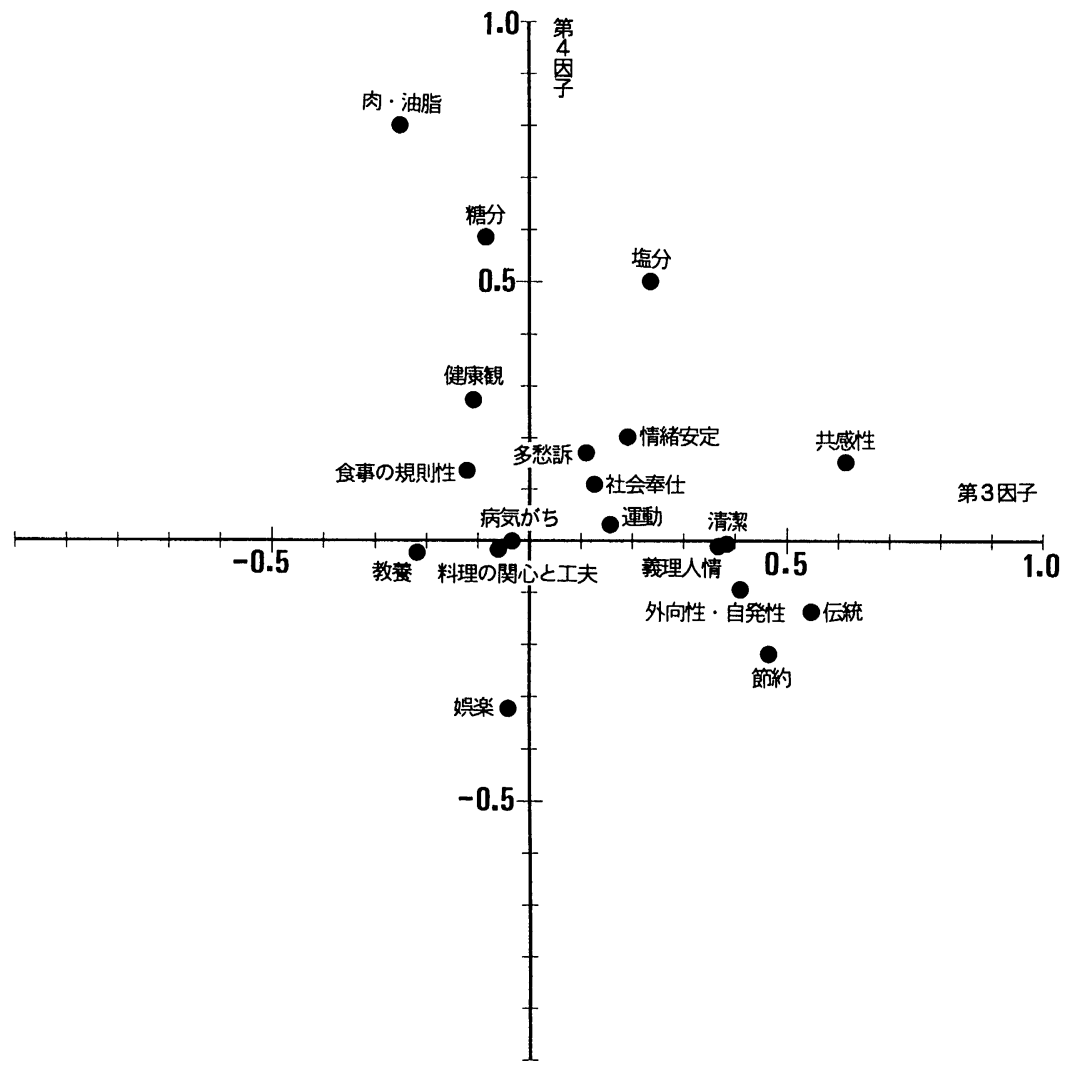

図 3 生活習慣等の状況（女性高齢者）

因子分析による空間付置（第 $3 \cdot 4$ 因子）

表 6 生活形態別の因子得点の相違

\begin{tabular}{lrrc}
\hline & 一人暮らし & 夫婦暮らし & \multicolumn{1}{c}{$\mathrm{p}$} \\
\hline 第一因子得点 & -0.162 & 0.183 & 0.131 \\
第二因子得点 & -0.127 & 0.143 & 0.248 \\
第三因子得点 & -0.022 & 0.025 & 0.830 \\
第四因子得点 & 0.186 & -0.210 & 0.070 \\
\hline
\end{tabular}

示された.しかしながら，統計的な有意性が見ら れた尺度は, 一人暮らしについては教養のみ, 夫 婦暮らしでは伝統のみであり, 全対象についても 料理の関心と工夫, 清潔, および第 1 因子得点の みとごく僅かであり,さらに本研究における対象 の年齢層（レンジ）が狭いことなどを考え合わせ ると, 本研究の場合には, 年齢の影響は大きくな いことが認められた。

\section{IV 考 察}

1. LPC 式生活習慣検査システム「生活習慣 ドック調査票」とその尺度について

ここで用いた尺度得点は LPC 式生活習慣調査 票の版権を持つ, 日本医療情報システム株式会社 により報告された尺度得点であり，各尺度につい て100点満点に変換された值である.なお，本調查 票のオリジナルである, 佐伯ら (1988), Takagi et. al. (1991) の報告では LPC 式生活習慣調査票より 得られる尺度は 23 尺度であるが，日本医療情報シ ステム株式会社より報告された結果では，佐伯ら の報告に比べ, 本研究で採用した資料では「洋風 の食事」,「飲酒・喫煙」,「妻主導型」の 3 尺度が なく，かっ「外向性」と「自発性」が合わさって 
表 7 年歯令と生活習慣の相関係数（一人暮らし・ 夫婦暮らし)

\begin{tabular}{|c|c|c|c|c|c|}
\hline & & & \multicolumn{2}{|c|}{ 一人暮らし 夫婦暮らし } & 全対象 \\
\hline 肉 & • 油 & 脂 & 0.023 & -0.247 & -0.032 \\
\hline 塩 & & 分 & 0.327 & -0.169 & 0.121 \\
\hline 糖 & & 分 & -0.063 & -0.237 & -0.067 \\
\hline 食 事 & 事の規則 & 性 & -0.189 & 0.047 & -0.138 \\
\hline 料理 & の関心と工二 & & -0.283 & -0.079 & $-0.330^{* *}$ \\
\hline 娛 & & 楽 & -0.022 & -0.084 & -0.220 \\
\hline 教 & & 養 & $-0.341^{*}$ & -0.118 & -0.190 \\
\hline 社 & 奉 & 仕 & -0.180 & -0.290 & -0.242 \\
\hline 義 & 理 人 & 情 & -0.299 & 0.135 & -0.176 \\
\hline 節 & & 約 & -0.040 & 0.086 & -0.102 \\
\hline 伝 & & 統 & -0.037 & $0.378^{*}$ & 0.069 \\
\hline 清 & & 潔 & -0.083 & -0.338 & $-0.247^{*}$ \\
\hline 運 & & 動 & -0.170 & -0.096 & -0.196 \\
\hline 病 & 気 が & $\hbar$ & -0.144 & -0.073 & -0.218 \\
\hline 多 & 愁 & 訴 & -0.041 & -0.043 & -0.089 \\
\hline 情 & 緒＼cjkstart安 & 定 & 0.061 & -0.245 & -0.052 \\
\hline 外向 & 性 - 自発 & & -0.218 & -0.223 & -0.228 \\
\hline 共 & 感 & 性 & -0.191 & -0.065 & -0.076 \\
\hline 健 & 康 & 観 & 0.098 & -0.008 & 0.021 \\
\hline 第 1 & 1 因子得， & 点 & -0.311 & -0.226 & $-0.319 * *$ \\
\hline 第 2 & 2 因子得， & & -0.016 & -0.076 & -0.118 \\
\hline 第 3 & 3 因子得， & & -0.029 & 0.064 & -0.001 \\
\hline 第 4 & 1 因子得， & 点 & 0.086 & -0.260 & 0.049 \\
\hline
\end{tabular}

「外向性・自発性」という新たな尺度が設けられて いた。ささに，「肉・油脂」，「塩分」，「糖分」，「病 気がち」,「情緒不安定」,「多愁訴」については, 質問の回答を反転して，いずれも回答が低い方が 高得点になるように変換されていた。本論文では, 「情緒不安定」については，日本医療情報システム 株式会社が命名した「情緒安定」という尺度名を 用いたが，その他の尺度については，反転されて いることを承知の上でそのままの尺度名を用い た。また同社より報告されなかった尺度に付いて は，分析から除外し，「外向性」と「自発性」が併 合された「外向性・自発性」についてはそのまま 使用した。これは，尺度が独立であることおよび 過去の多くの報告(日野原ら 1981，1982a，1982b， 佐伯ら1988，道場ら1985a，1985b，1987，1988， 1989, Takagi et al. 1991）において，「外向性」 と「自発性」が比較的類似した尺度であることを
考慮すれば，分析結果に大きな影響を与えること はないと考えられる。

また，質問票調査を実施する上で，最も大きな 問題となるのは使用する質問票の信頼性や妥当性 であるが, 本研究で用いた LPC 式生活習慣検査 質問票は，広く認められ，長期にわたり多くの被 験者に対して実施したデータに基づいて, 信頼性 や妥当性の検討は十分に行われている（日野原ら 1981，1982a，1982b，佐伯ら 1988，道場ら 1985a， 1985b, 1987, 1988, 1989, Takagi et al. 1991). 従って, 本研究の場合には, 質問票を使用する際 に必要とされる信頼性や内的妥当性についての検 証は行わなかった。

なお，質問票は本来婦人を対象として作成され たものであったが，独居や夫婦のみの高齢者に対 して行われた例はなく, そうした点から言えば本 調査が初めての対応であるといえる. 佐伯らが地 域在住の婦人 5,894 名を対象として, 本調査票のも ととなった LPC 式生活習慣検査を実施した例で は70歳代，80歳代の対象も含まれており，高齢者 への適応の問題はないと考えられる（佐伯ら 1988).

\section{2. 生活形態と生活習慣}

近年，高齢者の問題が取り立たされるようにな り，とくに地域在住の独居や夫婦のみの高齢者を 対象とした研究も行われて始めてはいるが, (荒木 ら1990，藤田ら1989，芳賀ら1988，岩崎ら 1993， 奥村ら1980)，多くはADLをはじめとする身体機 能や食物攝取状況についての報告である. 食物捸 取状況に関する研究結果によると, 男性の一人暮 らしは夫婦暮らしに比べ，おしなべて悪いが，女 性の場合は，一人暮らしと夫婦暮らしの間に著し い差は見られていない (Davis et al. 1985, 熊江 ら1986, 須山ら1989, 野崎ら1993, 松林ら 1994).

食物摂取状況と生活習慣では若干異なっている かも知れないが, 本研究の場合にも, 尺度得点に ついての両群間の $\mathrm{t}$ 検定で有意差が見られた尺度 は，「料理の関心と工夫」および「娛楽」の 2 尺度 のみであり，いずれも夫婦暮らしの方が尺度得点 が高くなっていた。 
他方，生活形態の状況を外的基準とした判別分 析によれば, 得点が高いことにより一人暮らしと， 低いことにより夫婦暮らしとそれぞれ判別される 可能性を高くする尺度として「教養」,「情緒安定」, 「共感性」が，逆に得点が高いことにより夫婦暮ら しと，低いことにより一人暮らしとそれぞれ判別 される可能性を高くする尺度として「食事の規則 性」,「料理の開心と工夫」,「娛楽」,「節約」,「病 気がち」,「健康感」が認められた。さらに $\mathrm{t}$ 検定で 有意差が見られた「料理の関心と工夫」と「娛楽」 の 2 尺度は, 判別分析においても標準化判別係数 の絶対值が大きな值を示しており，さらに標準化 判別係数の絶対值が大きい尺度では，有意ではな いが $\mathrm{t}$ 值が大きくなっており, $\mathrm{t}$ 検定と判別分析の 間には整合性が確認された。このことは，対象数 が增えればこうした尺度についての統計的な有意 差が認められる可能性がある。しかしながら，判 別分析により得られた結果では,一人暮らしでは, 「教養」,「情緒安定」,「共感性」の尺度得点が高く, 逆に「食事の規則性」，「料理の関心と工夫」，「娛 楽」,「節約」, 「病気がち」, 「健康感」の尺度得点 は小さいことを示すと考えられ，他方，夫婦暮ら しでは「教養」,「情緒安定」,「共感性」の尺度得 点が低く，逆に「食事の規則性」，「料理の関心と 工夫」, 「㛎楽」,「節約」, 「病気がち」, 「健康感」 の尺度得点は大きいことを示すと考えられる。し かし, 一人暮らし群では夫婦暮らし群に比べ, 配 偶者がいないという状況を考慮すると料理が単純 になったり，食事が不規則になることは予想され 得るし，ひとりということで娛楽に費やすことを 控えることも予想できる。 また，一人暮らしの方 が自分自身の健康には気をつけることも予想出来 得る。こうしたことを考慮した場合, 本研究で得 られた結果は至極当然な結果と言えると考えられ る.

以上の結果を総合すると, $\mathrm{t}$ 検定では明確な差 が現れず，高齢女性の場合には一人暮らし，夫婦 暮らしの別なく, 食生活に関しては独自に決定す る要素が多く，明確な差が生じないという既報告 例（左ら1984, 名倉ら1994）と一致した。さらに
老人の人生満足度等を 3 年間調查して, 独居老人 でも近所の人達とのコミュニケーションがある事 例では，心身の老化が防げ，独居していないもの と差がないという藤田ら（1989）の報告とも一致 する.しかしながら, 本研究の場合, 対象数が多 くなかったことを考慮すると，判別分析の結果に 現れた様な，「一人暮らし」と「夫婦暮らし」の相 違は，対象数が多くなればより明らかになること が予想され，食物搨取状況等とは異なり，生活習 慣の場合には，「一人暮らし」,「夫婦暮らし」とい う配偶者の有無による，影響は存在していると考 えられる。

\section{3. 生活習慣と年齢}

対象者全員が高齢者であるので生活条件の中で 高齢であるという部分は大きいと考えられる. 従って高齢者の生活全体を支配しているものを総 合的に分析する場合，特に年齢との関係に重点を 置いて検討する必要があると考えられる，本調査 の結果では, 生活習慣と年齢との相関関係につい てみたところ, 有意ではないが非常に多くの負相 関が出現した。このことは, 年齢の上昇に伴って, 生活状況が悪化するが，本研究で用いた対象の場 合，対象数が多くなかったことおよび，年龄が変 動係数で $5.6 \%$ と非常に狭い範囲に収まっており， 影響を考慮するに至らなかったものと考えられ る. 佐伯ら（1988）は生活習慣の結果に年噛階層 間の相違があることを報告しているが，これは 20 歳代から70歳以上まで年齢を 10 歳ずつの区分に分 けた際の相違であって, わずか 10 歳程度の範囲に 分布する集団では年齢による差異が見られないこ とは，止む得ないことと考えられる。しかし，本 研究の場合, 対象数が両群の合計で66名とあまり 多くはないので, 統計的な有意さが生じにくいこ とが考えられ，対象数が多くなれば年齢による差 が認められる可能性も捨てきれない.

4. 健康と暮らしの要約変量

個別の変量間の関係を要約的に説明し，一人暮 らし，夫婦暮らし各個人の生活習慣の状況を明ら かにする目的で，全対象者を用いて因子分析（主 因子法・バリマックス回転）を行い, 抽出された 
因子を要約変量とした。

この生活習慣尺度の第 1 因子は「社会奉仕」,「教 養」,「料理の関心と工夫」,「娛楽」,「運動」,「清 潔」, 「外向性・自発性」,「共感性」などの尺度の 負荷量が大きくなっており，日常生活における 様々な問題に対して関心を持ち，実行する傾向を 示している.つまり積極性や活発性, 行動力を示 す因子であり，その傾向は，これらの尺度の負荷 量が正であることから, 値が大きくなるに連れて 強まっている。また第 2 因子は,「多愁訴」,「情緒 安定」,「病気がち」などの尺度の負荷量が大きく なっており，不定愁訴や精神状態や疾病に対する 訴えが少なく，心身の状態が好ましい傾向を示し ている.その傾向は, 訴えが少ない場合に高得点 となる尺度の負荷量が正であることから, 值が大 きくなるに従ってより健全な状況にある. 第 3 因 子は，「共感性」，「伝統」，「節約」といった尺度の 負荷量が大きく，他人の気持ちをよく理解すると 同時に現実的で伝統的な生活を送る傾向を示して いる。このことは日常生活における堅実さを示す ものであり，その傾向はこれらの尺度の負荷量が 正であることから，值が大きいほど堅実な生活を 営んでいることになる。第 4 因子は「肉・油脂」, 「糖分」,「塩分」などの尺度の負荷量が大きく，食 事に関する因子である。その傾向は，これらの食 品の捸取量が少ない場合に高得点となる尺度の負 荷量が正であるので, 值が大きくなるに従い, 食 事がより良好になる。これらの 4 因子の累積寄与 率は，44.2\%であるから本研究の対象集団である 高齢者の生活習慣はこの 4 因子によって集約され ていると考えることが出来る.

佐伯ら (1988) は, 20歳代から80歳代の女性2,196 名を対象として LPC 式生活習慣調査を行い，本 研究と同様に因子分析（主因子法・バリマックス 回転）を行って 6 個の因子を抽出している。この 際得られた因子は, 第 1 因子：行動力, 第 2 因子： 積極性・活発さ，第 3 因子：生活の堅実さ，第 4 因子：心身の状態, 第 5 因子：食生活, 第 6 因子： 飲酒・喫煙であった.この結果と本研究の結果を 比較した場合, 本研究では佐伯らの結果における
第 1 因子と第 2 因子を併せたものが第 1 因子とな り，佐伯らの第 4 因子が第 2 因子に，第 3 因子が 第 3 因子に,第 5 因子が第 4 因子に対応している. このことは, 本研究で得られた因子は, 佐伯らが 尺度構成の基準とした集団における因子と一致し ており，言い換えれば，高龄者であっても生活習 慣を構成している要因については，青〜中年の婦 人と同じであり，これらの因子は我が国の女性の 生活習慣を規定する因子であると考えられる。

\section{V 結 論}

本研究は熊本市在住の高齢女性を対象とした公 開講座を開設し参集した一人暮らし高齢女性 (35 名), 夫婦暮らし高齢女性 (31名), 計66名につい て生活習慣の把握を目的として「LPC 式生活習慣 ドック調查」を実施し, 高齢女性の生活習慣の状 況を一人暮らし, 夫婦暮らしについて比較検討し た.

1）生活習慣尺度から見た場合,女性の一人暮ら しと夫婦暮らし高齢者の間でいくつかの尺度で差 が見られ，配偶者の有無による影響が認められた。 このことは, 高齢女性では, 配偶者の有無による 差はほとんど見られないという，食物摂取等につ いての過去の報告とは異なる結果であった。

2）個人の生活習慣の背景となる, 生活習慣の因 子については, 既に報告されている若年層や中高 年で得られた因子とほぼ同様な因子が抽出され た。これは，我が国の婦人の生活習慣に内在する 基本的な性質の因子であると推察出来る.

稿を終えるにあたり，本研究に多大なご支援を戴き ました尚絅短期大学三村悟郎学長, ならびにご指導を 賜りました東邦大学医学部公衆衛生学講座豊川裕之教 授に深謝申し上げます。

\section{文献}

荒木紀代子, 藤丸知子, 宮本秀美, 他 (1990)：1人 暮らし老人の心の健康と生活状況との関連につい て, 保健婦雑誌, 46, 140-148

Davis, M.A., Randall, E., Forthofer, R.N., Lee, E.S. \& Margen, S. (1985): Living Arrangement and Dietary Patterns of Older Adults in the United 
States, Journal of Gerontology, 40, 434-442

道場信孝, 日野原重明 (1095a)：健康教育, 生活習慣 の変容, 21世紀へ向けての医学々医療(編集)，21世 紀へ向けての医学と医療研究班, 109-127, 日本評論 社(東京)

道場信孝, 松島たつ子, 日野原重明, 柳井晴夫, 高木 廣文 (1985b)：心臓りハビリテーションに関連し た患者プロフィールの問題点一生活習慣の変容, 行 動類型，および，性生活について一，治療，67, 133 $-138$

道場信孝（1987）：成人期における健康教育，21世紀 に向けての医学々医療, 日野原重明 編, 健康教育, 109-154，日本評論社(東京)

道場信孝, 佐伯圭一郎, 高木広文, 柳井晴夫, 日野原 重明（1988）：虚血性心疾患のリスクファクター(2) 集団管理と個人管理一個人：運動と食事，日本循環 器管理研究協議会雑誌, 22 (3), 307-312

道場信孝，日野原重明，高木廣文，佐伯圭一郎 (1989）： LPC 式生活習慣検查, 冠動脈瀬威信疾患危険因子と の関連及び運動療法の効果の評価について，Therap. Res, 10 (1), 100-107

藤田長太郎，松永文保，吉福健二，平間美代子，直塚 和子，城代千鶴子（1989）：独居生活が心身の老化 に及ぼす影響について一高来町独居老人調查 3 力年 の経過一，社会精神医学，12, 353-359

芳賀 博, 柴田 博, 松崎俊久, 安村誠司 (1988)：地 域老人の日常生活動作能力に関する追跡的研究，民 族衛生, $54,217-233$

左 篤子，棺本六良，中里富美子，高原順子 (1984)： 老人の栄養紊摂取量に及ほす生活環境や生活身体状 況の影響, 日本公衛誌，31，615-621

日野原重明，柳井晴夫，柏木恵子，他（1981）：健康 生活の処方に関する基本的研究一生活習慣の調查 一. 第 1 回医学・生物学に関する情報学連合大会, $139-242$

日野原重明，柳井晴夫，高木廣文，柏木恵子，日野原 緑 (1982a)： 循環器疾患予防のための生活習慣に 関する研究 (第 1 報) 生活習慣の多变量解析による分 析, 日本公衛誌, 29 (7), 309-320

日野原重明, 柳井晴夫, 高木廣文, 柏木恵子, 日野原 緑 (1982b)： 生活習慣の調査一食生活尺度につい て一, 厚生の指標, 29 (12), 3-19

岩崎 清, 芳賀 博, 中村洋一, 他 (1993)：高齢者 の日常生活行動と健康, 社会老年学, $29,86-92$
厚生省人工問題研究所 (1992)：日本の将来推計人口, 研究資料 274

厚生省人工問題研究所（1995）：日本の世帯数の将来 推計, 研究資料 283

熊江 隆, 菅原和夫, 木下喜子, 町田和彦, 島岡 章 (1986)： 高齿者の栄養素掑取に及ぽす家族構成の 影響, 日本公衛誌，33，729-739

松林公蔵，和田知子，奥宮清人，他 (1994)：老年者 の包括的健康度に関する地域比較研究一高知 - 奥久 島一V一情緒ならびら Quality of Life (QOL)一, 日 本老年医学会雑誌，31，790-799

三宅一郎, 山本嘉一郎, 垂水共之, 白倉幸男, 小野寺 孝義 (1991)：新版 SPSSx III解析編 2, 東洋経済新 報社(東京)

名倉育子, 多田羅浩三，新庄文明，他（1994）：地域 の独居老人の給食サービスの利用希望に関する要 因，日本公衛誌，41, 253-261

野崎昭彦，喜多義邦，上島弘嗣，他（1993）：滋賀県 の一農山村地域における独居老人，老夫婦世帯老人 及び在宅寝たきり老人の健康状態について比較研 究: 有病率, 血圧, 心電図, 血液検査所見を中心に, 日本公衛誌，40, 850-858

奥村富美子，岡安やす子，小林まり子，倉茂邦子，平 山まゆみ, 島崎妙子（1980）：独居老人食生活実態 調査のまとめ, 臨床栄養, $57,271-278$

佐伯圭一郎, 高木廣文, 日野原重明, 柳井晴夫, 道場 信孝, 水口 緑 (1988)： LPC 式生活習慣検查の作 成, 行動計量学, 15 (2), 32-44

須山靖男，芳賀 博，柴田 博，松崎俊久，鈴木一夫 (1989）：地域在宅老人の食品摂取パタンに関連す る要因, 老人社会科学, $11,264-282$

Takagi, H., Saiki, K., Hinohara, S., Yanai, H., Douba, N. \& Mizuguchi, M. (1991): Construction of the Life Habits Inventory, Suzuki S. \& Roberts, R.E., eds., Methods and Application in Mental Health Surveys: The Todai Health Index, 103-121 \& 297-306, University of Tokyo Press (Tokyo)

高木廣文 (1994)： HALBAU-4 マニュアル, 現代数学 社(京都)

高木廣文（1995）：へルスサイエンスのための統計科 学 8. 判別分析と多重ロジスティックモデル, 医学 のあゆみ, 174 (4), 285-289

（受稿 至急 1995.9.25；受理 1996.2.16） 